\title{
Community-based management of the Mediterranean coastal fisheries: Historical reminiscence or the root for new fisheries governance?
}

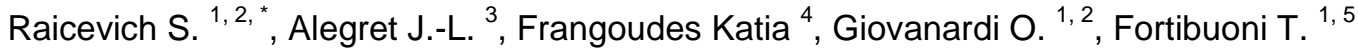 \\ ${ }^{1}$ Italian National Institute for Environmental Protection and Research (ISPRA), Chioggia, Italy \\ 2 Institute of Marine Sciences, National Research Council (ISMAR-CNR), Ancona, Italy \\ ${ }^{3}$ Universitat de Girona, Girona, Spain \\ ${ }^{4}$ Univ Brest, Ifremer, CNRS, UMR 6308, AMURE, IUEM, 29280 Plouzané, France \\ ${ }^{5}$ ECHO Group, Division of Oceanography, National Institute of Oceanography and Experimental \\ Geophysics (OGS), Trieste, Italy \\ * Corresponding author : S. Raicevich, email address : sasa.raicevich@isprambiente.it
}

\begin{abstract}
:
Historical management experiences of Mediterranean community-based fisheries were particularly effective in fostering both social cohesion and sustainable utilisation of coastal resources. This figure contrasts with the current status of Mediterranean fisheries, where about $90 \%$ of stocks are overexploited. The key question then is: can past experiences guide our current approach to reshaping governance in the Mediterranean fisheries? In our effort to answer this question, we analyzed the main attributes of selected fishing governance systems in the Early and Mid-Modern period and their evolution through time. We focussed on the Spanish Cofradías, the French Prud'homies and the Venetian Fraglie (Italy). They were characterized by the establishment of territorial user rights system of management and governed technical aspects of the fisheries, market access, and restrictions. Fishers and their communities, through their corporations/organizations, were directly involved in legislating and enforcing management policies and regulations/rules. This approach to fisheries management differs from the one introduced by the EU Common Fisheries Policy (CFP), established in the late 1970s, which was mainly top-down. Despite the systematic efforts to reduce fishing capacity and pressure on marine resources and to impose severe technical and restrictive measures, Mediterranean fisheries are still in bad conditions. To cope with this situation the EU recently reformed the CFP establishing, among other things, a new paradigm that seeks to foster the harmonization of the decision-making process in the context of the so-called "regionalisation" of fisheries management. However, this policy does not clearly establish a proper community-based approach and restricts participation to national fishers' associations in the context of the Advisory Council of the Mediterranean Sea. Without effectively linking local and regional fisheries management structures by engaging fishers and re-establishing a sense of community through providing community-based rights for fishing, this new effort will likely not succeed in achieving Mediterranean fisheries sustainability.
\end{abstract}




\section{Highlights}

- Cofradías, Prud'homies, Fraglie were historical forms of fishers' organizations. They regulated fishing activities and access to fishery resources in coastal areas. Their role is now less relevant in Mediterranean fisheries management. The Common Fisheries Policy is now shifting towards a regionalized approach. These entities might play a role in linking local to regional fisheries management.

Keywords : Co-management, Common Fisheries Policy, Cofradiaś, Prud'homies, Fraglie, Advisory council 


\section{Introduction}

53 The Mediterranean Sea is a Large Marine Ecosystem characterized by a high biodiversity and a long

history of fishery exploitation, dating back to the Paleolithic period (approx. 20.000 years B.C.; Coll et al., 2010). From historical times marine resources exploitation was characterized by the prevalence of small-scale fisheries (SSF) mostly operating in coastal and inshore areas. Similarly, at present about $80 \%$ of Mediterranean Sea fishing vessels belong to SSF (FAO, 2016). Fishery resources are showing high signs of overexploitation, with about $90 \%$ of assessed stocks exploited above Maximum Sustainable Yield (MSY) limits (Tsikliras et al., 2015).

This condition represents a clear failure of both the General Fisheries Commission for the Mediterranean (GFCM) and the European Union (EU) fisheries policies, executed through the implementation of Common Fisheries Policy (CFP). All EU Member States sharing national waters in the Mediterranean Sea, i.e. Spain, France, Italy, Croatia, Slovenia, Malta, Greece, and Cyprus are supposed to implement the policies and regulations of the CFP related to Mediterranean Fisheries management. According to Cardinale and Scarcella (2017), the failure of EU fisheries management in the Mediterranean Sea is a result of the limited effectiveness of the approach based on the establishment of technical measures and fishing capacity/effort limitations. In particular, the adoption result in a tangible reduction of fish mortality on targeted stocks. Evidently, the weakness of

71 Mediterranean fisheries management is the result of low level of compliance and non-enforcement of 72 rules, the continuous non-adherence to scientific advice and the ineffectiveness of national management plans (Cardinale and Scarcella, 2017). 
However, these technical explanations seem to represent only one part of the story. Indeed, until recent years, the European Commission and Council of Ministers mainly based the governance system adopted by the EU through CFP (revised in 2002 and 2013 since its inception in the 1970's) on a top-down approach. Since the 2002 CFP reform, the decision-making process was changed through the establishment of the Regional Advisory Councils (RAC), later renamed Mediterranean Advisory Council (MEDAC). Advisory Councils re-established the relationship between all the stakeholders in the Mediterranean fisheries (industry, fishers, non-governmental organizations, consumers etc.). The main aim of the Advisory Councils is to advise the European Commission on all new regulations, rules and sub-regional fisheries management plans. This fundamental change in the decision-making processes was complemented by the co-decision power given to EU Parliament.

These two fundamental changes diminished the power of the Commission over resources management but did not substantially improve local fisher communities' participation in the resource management decision-making process. This is because fisheries management was mainly oriented to satisfy the needs and aims of large-scale vessels targeting both demersal and small/large pelagic fish, and not SSF that is more rooted in fisheries communities.

Such approach contrasts with historical experiences of local management in the area that were characterized by diverse forms of locally-rooted fisheries co-management approaches, as in the case of Cofradias (Spain), Prud'homies (France) and Fraglie (Italy). Territorial use rights for fisheries (TURFs), access restrictions to resources (given only to male members of the community) and technical restrictions characterized these organisations. Fishers and their communities/corporations were directly involved in establishing and enforcing management rules. These characteristics of local based management are similar to some of the key attributes of co-management, which is currently regarded as a potential alternative or a complementary approach to top-down management, being suggested as a means that could allow achieving sustainability goals (Gutierrez et al., 2011). 
In a global study of the attributes of co-management systems in fisheries, Gutierrez et al. (2011) identified several variables that should allow for the prediction of the potential success of comanagement. These included strong leadership; the presence of catch sharing by quota; the establishment of TURFs; the presence of Marine Protected Areas (MPAs); social cohesion; and selfenforcing of regulations.

Jentoft (2003) defined co-management or community-based management as the collaborative and participatory process of regulatory decision-making between representatives of user groups, governmental agencies, research institutions, and other stakeholders. According to Gutierrez (2013), co-management refers to a set of arrangements with different degrees of power-sharing, allowing joint decision-making by the decision state and user groups about a set of resources or an area. Moreover, it entails institutionalized arrangements for users' participation in management and decision-making. Accordingly, ad hoc public participation in management decisions or mere consultation is often not regarded as co-management (Gutierrez, 2013).

Whilst this definition would include MEDAC establishment as a co-management tool acting at regional (i.e. Mediterranean) scale, we point our attention to the engagement of local communities in co-managing local fishing, and its relation to broader scale management. In particular, in this paper, we reflect on the historical features that characterized local fisheries management systems and their evolution in the Mediterranean Sea. The aim is to understand whether such experiences could contribute to improving the current governance and achieve fisheries sustainability in the Mediterranean Sea.

To achieve this research aim, we applied the following approach:

i) We described the historical evolution of Cofradias, Prud'homies, and Fraglie since their establishment to the present and investigating the presence of the attributes of success identified by Gutierrez et al. (2011); 
ii) We described the last process of evolution of CFP in the Mediterranean Sea, reflecting on its capability to foster more decentralized governance and the growth of the direct involvement of local fisher communities in co-management.

This analysis led our discussion on how to improve fisheries management in the Mediterranean Sea, with a special focus on SSF and local fishing communities.

\section{Historical evolution of local fishery management systems in the Mediterranean Sea}

\subsection{The Spanish Cofradías}

Contrary to common belief, the present Cofradias, as evidenced in the last seven decades, are not the same organization as for how they existed before in the Spanish Mediterranean fishing sector (Alegret, 1996; Fig. 1). The Cofradías were created as public law corporations in 1943, naming them with the same ancient designation of the religious medieval organizations Cofradias, literally meaning 'brotherhood' (Alegret, 1999a).

Before this, the fishing sector had different organizational structures in each historical period. In medieval times (from the XII to XVII centuries), Cofradías existed as religious associations dedicated to the service of saints, but also to a certain extent, concerned with the welfare and rescue of captives. From the XVIII century, the Gremios, which generally took the name of guilds of sailors or/and fishers, were the only type of organization until their dissolution halfway through the XIX century with the arrival of liberalism. They were characterized by complex decision-making and regulatory systems, which defined access rights for fishing in delimited areas, usually on limited sectors of the coastline, in relation to their spatial fishing area. They also had the power to impose fines against infringements. From this time and until the beginning of the dictatorial period, various forms of organizations appeared such as the Mutualidades (mutual benefit societies); Montepíos (charitable funds for dependents, friendly societies); Pósitos (association for cooperation or mutual aid between 
workers); Cooperatives, the Ligas (Leagues); Hermandades (Brotherhoods); the Sociedades Marítimas (Maritime Societies); Sindicatos (Trade Unions), etc.

At present each Cofradía undertakes the role of regulator and controller of access to resources for each of the different fleets operating within their territorial limits (base ports). Depending on the kind of fleets operating - small scale, trawling, longliners, purse-seiners - each Cofradía establishes for each of these fleets the schedules for port entry and exit and possible close season periods. Moreover, it stipulates a complete set of specific local norms for the area under its jurisdiction, including the specific zones of fishing activity for each type of fleet in accordance with the geographical, ecological, historical and social peculiarities of each place. That means they participate with the state in a co-management system centred on the Control of the Fishing Effort and not on the Total Allowable Catches (TACs) as applied in northern Europe.

The most important factor concerning the function of the Cofradias as mediator bodies is that they provide a social and legal arena wherein the majority of the conflicts arising within the sector can be resolved without asking for assistance from other institutions. Law determines the internal structure of the Cofradias. Given their corporate nature, all interests represented in the sector are given full representation by the law, without distinction/discrimination. However, within the organs of government and its representative bodies, the main distinction is between what is understood as the "economic part" (ship-owners/owners of the means of production), and the "social part" (sailors/those who sell their labour force). In this way, the interests of both groups are formally, equally and jointly represented in each governing body within the Cofradia.

The Junta General (general meeting) and the Cabildo (executive group) are organs which have equal representation from both the "economic" and the "social" parts through an election process which occurs every four years. However, neither the Junta nor the Cabildo act as mediating organs, since they limit themselves to the role of compliance with functions of representation and deliberation. In this context, the mediating figure par excellence is the Patrón Mayor (Main Skipper), elected among 
the members of the Cabildo and representing the president of the organization. The Patrón Mayor acts as a "good and true man" in solving the majority of conflicts arising within the sector and thus contributing to the continuity of the long Mediterranean tradition of the Catalan Prohomens or the French Prud'homies (described in the next section).

Since 1987, the new democratic state tried to introduce in the fishing sector (however unsuccessfully until recent times) a new type of fishers' organization proposed by the European Economic Community (EEC), i.e. the Fishers Producers Organisation (FPO). FPOs fundamental objective was making possible that catches were adjusted to meet demand and that the producers benefitted from their participation in the marketing process, something that the historical Cofradias did not do. The reasons for this failure need to be found, amongst other things, in the socio-political cost that would have resulted from displacing the Cofradias from their role. This change would have created a power vacuum that would provoke an increase in social and political costs, in many aspects not comparable to the reduction in transaction costs that theoretically they could have gained with the implementation of the FPOs (Alegret, 1999b).

However, the problem of adjusting captures to demand and the participation of the fishers in the process of marketing continues to be a real and very significant problem. Now, the Cofradías and their Federations are incapable of responding to the changes imposed by the market, leading the Cofradias to a situation of quasi non-operation in the representation of the global market interests of the sector, and more specifically to lose bargaining power in front of the merchants that now dominate the process of assigning prices. In addition, Cofradias are losing power in front to the administration, that began not seeing them as the true co-management instruments (as they were historically), with consequences that will be difficult to foresee. 
Ninety percent of fisheries activity in French Mediterranean (Fig. 1) is practised by fishing vessels less than $12 \mathrm{~m}$ long, using different types of gears, longlines, gillnets, pots, and others, targeting different species according to seasons and changing gears according to the targeting species (SSF). The species having the highest commercial value are flatfish, hake, sea bream, eels, molluscs, and crustaceans (WWF, 2009).

Nowadays, in French Mediterranean there are two main organizations regrouping all active fishers. The first and oldest is the Prud'homie, established in 1000 and regrouping mainly small-scale fishers; the second is the Regional Committees of Fisheries (CRPM), established in 1945 and reformed several times. Nowadays, there are 32 Prud'homies of variable size (Decugis, 2009) in the state of membership and territory, and 3 CRPM covering larger territories (Province Côte D'Azur, Languedoc-Roussillon and Corsica). Both organizations are elected by fishers and have the responsibility of one territory in which they must manage the fisheries activity.

Some differences exist between the two organizations. Firstly, Prud'homies are local organizations and represent somehow the communities, while CRPM act in larger territories. The second difference is that Prud'homies members are mainly small-scale fishers, while those of CRPM belong to all fishing fleets (SSF, purse seines, and trawlers). For many years, big boat owners dominated CRPM decisional bodies. This situation temporarily changed in 2012 , when the SSF won the elections, but could change with the next elections.

The Prud'homies are a Mediterranean institution and, according to some researchers (Chaboud et al., 2015), their birth can be explained by the presence of a big number of lagoons on this coastline and the necessity to manage the activity of different gears within lagoon's territory. The first Prud'homie was established in Marseille, and all persons practising fisheries should be members. Prud'hommes, experienced fishers elected by local fishers, had the power to regulate fisheries activities of different gears operating within their territory with the objective to prevent conflicts and clashes between fishers. This type of organization stemmed from the brotherhoods and the corporations of the Older Regime, since Prud'homies were not abolished during the Revolution like other corporations (Faget, 
2013, Féral, 1990). Indeed, representatives of the Prud'homies of Marseille had pleaded their case in front of the Constituent Assembly by bringing up the support that fishers brought to the revolution and about the importance of their organizations to ensure the social peace within coastal communities. Therefore, Prud'homies were confirmed in their attributions by the Assembly and were allowed to spread to others fisheries communities where they did not exist.

Nowadays, almost each fishing community has a Prud'homie, which manages, regulates and supervises its fishing territory (Décugis, 2009; Frangoudes, 1997, 2001, 2005). They are democratic institutions and regroup only the boat owners. All members vote regulations concerning fisheries to the majority at the end of each general assembly. Prud'homies action concerns only small gears, lagoon fishing, and SSF. Prud'homies represent a strong identification between a community and its fishing territory (Cazalet, 2013; Décugis, 2009; Féral, 1986a,b; Frangoudes, 1997; Tempier, 1985, 1986).

Thus, the Prud'homies manage fishing activities with few main objectives. The first is to guarantee an equitable distribution of resources between fishers. The drawing lots of fishing posts or the strict regulation of access conditions, which are mutual for fishing areas managed by neighbouring Prud'homies, are also an illustration. The study of conflicts arbitration between fishers within a group shows that this argument of equity, which is defined by "each one must live correctly of his trade", holds a central place. Then, they manage the resources exploitation by implementing different limitations: exit time, the size of the net meshes or seasonal interdictions of fishing. Finally, the Prud'homie controls the access to the profession avoiding a strong growth of the number of fishers, which would question the right of each fisher to "live correctly of his trade". However, a responsibility feeling towards the local society counterbalances this restrictive vision. "The most important number of families must live decently of fishing" or "fishing cannot be refused to person not having another possibility of livelihood" are arguments found in Prud'homies archives. Of course, these principles are far from the liberal argumentation, which characterizes some current speeches in favour of resources privatization. 
The Prud'hommes are elected by the Assembly and have jurisdictional functions. They can judge conflicts between fishers or the infractions committed within the territory under their responsibility. They are also the guarantor of the respect of non-written rules. Their juridical existence is limited to the conciliation of conflicts affecting the social order of fishers' community operating on a given territory.

Prud'hommes are enjoying important powers within the French constitutional context (right of judgment and no contesting of the judgment), but their action field in the practice is reduced compared to the Spanish Cofradias. The political and institutional evolution of France has done that the Prud'homies have been more tolerated than encouraged. During a time, they have been viewed as a model to generalize on the whole of maritime facades. After, they have been submitted to a constant pressure, which aims to reduce their means and their action field for the benefit of a national pyramidal and professional structure, the Local Fisheries Committees, and the National Committees. These organizations, which at the beginning were not elected and did not have competency in resources management, evolved with time. Different changes of the laws (1992, 1998, and 2010) accorded to them the power to manage the resources within the 12 nautical miles (NM) area belonging to the maritime territory of the regions. Boat owners, crew members and employees of fishing enterprises elect decisional bodies of the committees. Producer's organizations participate also to the committees. Nowadays, Regional and National Fisheries committees are responsible for resolving conflicts between gears occurring within the $12 \mathrm{NM}$ zone under their territory, produce management rules (e.g. seasonal or areas closures) and deliver licenses based either on gear basis (nets, trawlers, purse seines) either on species.

At the Mediterranean level, the different reforms of the committees divided the skills between the two institutions: the Prud'homies have the conciliation power and resources management at local level, while the fisheries committees have the power of resources management at regional and national levels. The Prud'homies are independent from the fisheries committees and still conduct their activity in the same manner as in the past. Fishers elect 4 to 7 Prud'hommes every three years, having 
the responsibility to manage the activity within a defined territory, which is growing due to the decreasing number of fishers. Nowadays, Prud'homies are involved in the conservation of marine biodiversity. For example, the Prud'homie of Saint Raphael designated an area of 400 hectares reaching up to $80 \mathrm{~m}$ of depth as fisheries reserve (Décugis, 2009).

Although the objective of the two organizations (Prud'homies and CRPM) remains the same, namely resources management, the main element that differentiates them is an issue of power. Within the committees, power is held by the larger fleet to the detriment of small-scale fleets, while in the midst of Prud'homies power continues to be an affair of SSF.

\subsection{The Venetian Fraglie and their heirs}

From the XI to the beginning of the XIX centuries, during the Repubblica Serenissima domain, in the Venetian lagoon (Northwestern Adriatic Sea, Fig. 1) fishers were organized in corporations called Fraglie.

The Fraglie were directly involved in resource ownership and management, their own interests being to exploit resources in a sustainable way. The Fraglie had an exclusive control over some fishing grounds, where only fishers affiliated to the corporation were allowed to fish, introducing a sort of "restricted access" in lagoon resource management (Fortibuoni et al., 2014). Moreover, these corporations had the power to repress abuses, control and punish fishers who did not respect regulations and denounce them to the Repubblica Serenissima. The punishment was severe, including the cutting of ears, imprisonment, and the impoundment of boats and fishing gear ("Senato Veneto" decree of 3 October 1760).

Every two years, the Fraglie elected two old and skilled fishers, who were responsible for controlling fishing activities. The Venetian Authority had to consult the fishers' representatives belonging to the Fraglie when implementing laws regarding fishery management, in order to take advantage of their experience and traditional knowledge (Scarpa, 1996). Regulations governed restrictions on fishing 
gear, fishing seasons, the number of fishermen, the commercial size of fish, their conservation and trade.

The direct involvement of fishers' corporations in fishery management in a sort of early comanagement scheme ensured the effectiveness of adopted legislation (Levi-Morenos, 1919) and avoided the so-called "tragedy of the commons" (Hardin, 1968). Indeed, it was in the fishers' interest to preserve lagoon resources in the long term.

The fall of the Repubblica Serenissima in 1797 was followed by a progressive deregulation of fishing activities that was probably a consequence of the political instability of the area and of the widespread poverty that afflicted local inhabitants (Levi-Morenos, 1919; Neil, 2002). Formally, during the occupying French "Provisional Government of the Municipality of Venice" (1805-1814) and later during the first decades of the Austrian government, many of the laws and regulations concerning fishery were maintained. However, the real novelty introduced by the Austrian government was the abolition of all of the corporations, including fishers' corporations. The abolition of the Fraglie resulted in a shift from restricted (controlled) access to open access to the fishery. By abolishing the Fraglie, an efficient tool for the management of lagoon resources was removed and, as a result, towards the end of the Austrian domination the control of fishing activities was less rigorous while private interests (e.g. illegal fry fishery) began to predominate (Levi-Morenos, 1919).

By the end of the XIX century, a dramatic decrease in yields was observed, and the widespread use of prohibited gear and the general lack of controls by the authorities were considered the main causes of the decline in the abundance of fish (Fortibuoni et al., 2014). Control and monitoring are two basic requirements to ensure the sustainability of socio-ecological systems (Ostrom, 2009), and since the end of the XVIII century, they were guaranteed by the Fraglie. Indeed, legislation of the Repubblica Serenissima mainly based the repression of illegal fishing on Fraglie (Fortibuoni et al., 2014).

In the $20^{\text {th }}$ century fishery in the lagoon became over time less important. Nowadays, fishers are grouped into local cooperatives, whose role is mainly to support members for practical administrative 
issues, as well as providing them information on management rules under development. Most often local cooperatives belong to regional branches of national fishers' organizations that represent the main actors in relation to the regional and national central administrations. Various fishing métiers are represented within national and regional fishers' organizations. This results in the challenge of finding the balance between the needs of individual members and the fishing métier (Buonfiglio et al., 2011). In addition, fishers' organizations have a limited capability to influence and guide fishers' activities toward more sustainable and economically efficient fishing practices. Only in some specific sectors and areas, e.g. SSF in Sicily (Raicevich et al., in press, a), Local Management Plans were established with the direct engagement of fishers in defining management rules.

In the case of Veneto Region, the administrative area where the Venice lagoon is located, recently (2017) a consortium involving small-scale fishers was established. However, this group is still far from presenting the same specificities and power of the Fraglie. Indeed, most of the representative power is held by regional fishers' organizations (three main federations, which were established after World War II, and two new federations). In this geographical context, some FPOs (e.g. small pelagics, bivalves) are also present as well as consortiums. Overall, this condition leads fishers to the perception of being out of the management decision-making process, with a general mistrust in relation to fishers' representatives' capability to really represent fishers' interests (Raicevich and Giovanardi, 2013; Raicevich et al., in press, b).

\section{Common Fisheries Policy (CFP) in the Mediterranean Sea: from top-down to regionalized} approach

Traditional local fisheries management systems of the Mediterranean Sea had to face, in the last sixty years, the application of policies defined at European level in the context of the CFP. Within the Treaty of Rome (EEC, 1957), fisheries management rules were embedded into the Common Agricultural Policy. Indeed, Article 38 of the Treaty defines agricultural products as 'the products of 
the soil, of stock-farming and of fisheries and products of first-stage processing directly related to these products'. The first attempt to regulate fishing as a separate entity resulted in issuing in 1970 the Regulation 2141/70 (EEC, 1970a) laying down a "Common Structural Policy for the Fishing Industry" and Regulation No. 2142/70 (EEC, 1970b), that dealt with the common organization of the market in fishery products (Song, 1995; Churchill, 1977). The principle of equal access to fishing zones (beyond national waters, at that time set at 3 NM from coastline) was partially revised in 1972 owing to a compromise (i.e. 10 years derogation) established with the new members accessing the EEC, i.e. Denmark, Ireland and United Kingdom, who were willing to protect their national fishing interests (Song, 1995). In 1976 the Commission, considering the spread of 200 NM Exclusive Economic Zones (EEZs) in the North Atlantic States, established a series of proposals later on adopted by the Council, that fostered the adoption by the North Sea and North Atlantic member states of the extension of their fishing limits to 200 NM from the beginning of 1977 (Song, 1995).

In 1983, a set of Council Regulations defined the objectives and instruments of a coherent CFP. The Regulation 170/1983 (EEC, 1983) established arrangement on the marketing policy, the adoption of TACs, technical conservations measures and the structural policy. However, many shortcomings arose over time, including the mismatch between quota set by member states in relation to scientific advice, high discarding rates, lack of long-term perspective in scientific advice, overcapacity and so on (Song, 1995).

This prompted to the revision of the CFP in 1992 (Regulation (EEC) No 3760/92; EEC, 1992) that contained structural measures to reduce fishing capacity along with the establishment of effective licensing systems. Given the little results on preventing overfishing, a further reform was set in 2002 (Framework Regulation (EC) No 2371/2002; EC, 2002) with the primary objective of ensuring a sustainable future for the fisheries sector while preserving marine ecosystems.

The regulation established the RACs to increase the engagement of fishers, scientific experts, representatives of other sectors related to fisheries and aquaculture, regional and national authorities, 
environmental groups and consumers. These advisory bodies should provide suggestions in the "predecision phase" of management measures. However, the effectiveness of such approach, due to the lack of clear derogation of power (i.e. providing RAC with an effective management role and power), was considered by some scholars rather insufficient (Gray and Hatchard, 2003).

At Mediterranean Sea scale the regulation Reg. EC 1967/2006 (EC, 2006) introduced technical limitations, minimum landing size and a range of technical measures which resulted in the interruption of several fishing derogations formerly granted to some local fishing activities (Raicevich et al., in press, a). The CFP was later on revised (Reg. 1380/2013; EU, 2013), introducing the target of reaching by 2015 or 2020, at the latest, stock size compatible with MSY, along with landing obligation. In reference to the focus of this paper, the regionalization was also established. Such process enhanced the role of Advisory Councils as consultative bodies in the definition of regional policies and, in particular, for setting multiannual long-term management plans. However, as noted by Salomon et al. (2014), the reformed role of Advisory Councils will gain traction only if member states will be willing to cooperate and develop together a coherent regional strategy, which will anyway need the Commission approval.

According to the EU Regulation on European Maritime and Fisheries Fund (EMFF; Reg. (EU) No 508/2014; EU, 2014), the "implementation of community-led local development strategies strengthening the role of fisheries communities in local development and the governance of local fisheries resources and maritime activities" (art 63, EU 2014) is also part of CFP objectives. This responsibility is given to the Fisheries Local Action Groups (FLAGs, already established as Local Action Groups within the former CFP). This role is partially overlapped to the role historically played by Cofradias, Prud'homies, and Fraglie. However, the composition of FLAGs is broader (i.e. not only fishers, but also representatives of the public, private and civil society sectors), and their objectives are more focused on increasing employment and territorial cohesion rather than on local based management of fishery resources. 


\section{Discussion}

400

401

402

403

404

405

406

407

408

409

410

411

412

413

This essay deals with the rediscovery of historical attributes of local fisheries management systems and their current expression, and relates them to the evolution of EU CFP as implemented in the Mediterranean Sea. What we have described so far are two parallel processes. On the one hand, the shift from a relevant role of local fishing communities where, in historical times, access to fishing (including TURFs, definition of local rules) were mediated by local self-organized bodies recognized by the central state (Tab. 1), towards an increasing role of national states and their administrative bodies, along with the emergence of fishermen national associations. On the other hand, the shift from an EU command and control top-down approach towards a gradual enhancement of the consultative role of regional bodies (Advisory Councils), whose effectiveness is determined, among others, by the willingness of national states to collaborate (Salomon et al., 2014).

In the past fishers' communities focused mainly on ensuring the persistence of fishing to provide livelihoods to their members (via the establishment of access rules to prevent foreigners' fishers to exploit local resources, but also imposing technical limitations to fishing) and a sort of welfare support to fishers and their families. These roles, over time, were only partially maintained due to the emergence of the national states and of national fishers' organizations (France, Italy), or also, as in the case of Fraglie, because such historical organizations ceased to exist.

In the last sixty years, the emergence of international policies within EEC and EU reinforced the role of national states and national fishers' organizations in the designation of policies. Fisher's organization, since the introduction of Advisory Councils, had the opportunity to be involved in the process of fisheries management. However, while some historical local fishing organizations still maintained a role to date, their capability to influence structural changes in fishing and its resources at regional level became more limited. At the same time, the spread of overcapacity (first after World War II and, then, with European Community) and the effects of technological innovation (as drivers 
towards unsustainability, when not associated with access limitations), and markets globalization, further increased the challenges to be tackled, making not possible to local communities to cope with them. In such dynamic context (that includes also social transformations, e.g. the arrival to the mainland of French fishers from Morocco and Algeria), with the overlay of multiple métiers (and thus contrasting interests) and the emergence of the industrial fishery, local fishing communities lost their historical capability to have their say into the management discourse.

Moreover, fisheries management has become a far more technical and scientific issue, being guided by concepts that fishers hardly manipulate (e.g. MSY). In this context, the role of science as a provider of the knowledge base to fisheries management becomes essential (Wilson et al., 2006; Wilson, 2009), and replaced almost completely fishers' knowledge. The latter is most often formulated according to metrics (and languages) that are not easily compatible with standard science (Raicevich et al., 2011).

Experiences developed among and beyond Europe in relation to participatory science shows, however, that fishers can fruitfully collaborate with scientist to co-construct such knowledge base (Mackinson and Wilson, 2014; Frangoudes et al., 2015, Stephenson et al., 2016), although there is a need to find the right endpoint where such knowledge may contribute effectively in setting management rules.

In the Mediterranean Sea, some successful examples exist. For instance, in the case of Spain, the local Cofradía of Palamós in the Costa Brava, exploiting red shrimp (Aristeus antennatus) as the main target species, was able, thanks to the collaboration with research institutions (Universitat de Girona; CSIC) and NGOs (WWF), to put forward a Local Management Plan that was later on endorsed by Spanish law (MAPAMA, 2013). Furthermore, small-scale fishers working in the Spanish Mediterranean and in Tuscany (Italy) were able to establish two long-term management plans (endorsed by EU, according to EU Reg. 1967/2006) for fishing sand eels (Gymnammodytes cicerelus) and small transparent goby (Aphia minuta). Different stakeholders and scientific institutions contributed to this process (Lleonart et al., 2014; Raicevich et al., in press, a). Moreover, in Sicily, a 
series of Local Management Plans pointing to co-management practices were established at the local level, thanks to the collaboration between fishers, their organizations and research institutes (Raicevich et al., in press, a).

Another example is represented by the Prud'homie of Saint Raphael, which established in 2003 the first fishing reserve in Cap Roux representing 500 hectares (Seytre and Francour, 2008). The Prud'homie of Saint Raphael manages this reserve and scientists of the University of Nice are in charge of the monitoring of the main species targeted by professional and not professional fishers. One of the main objectives of scientists is to identify the "reserve effect" within the area, but also in the periphery of the area where fishers are operating (spillover effect). With the implementation of this reserve, the Prud'homie is now not managing only professional fisheries but also recreational activity occurring in the area.

Such experiences, however, are not spread in the vast majority of the Mediterranean Sea. The capability to be further adopted is possibly linked to several local and regional conditions, including the presence of actors willing to play a sort of facilitator role in the process (e.g. NGOs or research institutes), along with the political will to adhere to such a process of power derogation.

In this context, the role of fishers' organizations (at both the national level and their local branches) emerges. Indeed, they are influential members of Advisory Councils, and they are able to influence national decisions and foster regional collaboration of member states. At the same time, the MEDAC showed to be able to support the formulation of common visions and advice to EU on issues of high relevance for the Mediterranean member states, like the landing obligation, or in its subareas (e.g. discard plan of striped venus clam Chamelea gallina and long-term management plan of small pelagic species in the Adriatic Sea). Thus, with the increasing role of national fishers' organizations in the decision making related to fisheries management towards national and EU authorities, the key issue of how local fishers' interests are represented and mediated, emerges. 
In particular, the effectiveness of fishers' organizations in addressing this role is partially criticized by some fishers. For instance, in a survey carried out within the ArtFISHMed project (dealing with artisanal fisheries in the Mediterranean), about half of interviewed fishers of the Veneto Region (Italy) considered the fishers' organizations not being able to represent their interests (ArtFISHMed, 2017) at the national level.

We argue that, in the current situation, the critical point is represented by the respective role of local communities and national fishers' organizations, in relation to two specific items: the capability to represent specific local issues at regional scale, and the nesting of management practices from local to regional scale and vice-versa. Attributes like "strong leadership" and "cohesion" (Gutierrez et al., 2011) are needed not only at local level. In this light, the capability of mediating different interests at the local level is essential but needs a strong democratic framework and forward-looking vision. In particular, only establishing a sense of community (like in historical times), and agreed frameworks to merge different management scales, could represent a potential solution to let local fishers be engaged in the management framework.

In this context, the adoption of co-management approaches, where every single fisherman have an active role and have a say, and where collective choices prevail on individual needs, seems to be an inevitable passage. With multiple potential benefits, including an increased capability to monitoring control and surveillance of the application of rules co-defined with fishers (Gutierrez, 2013). Moreover, as pointed out by Bavinck et al. (2015), premodern fishers' organization could contribute to management with their local knowledge, create social order, solve conflicts and assist in regulating fishing effort.

Whether and how the chain of power from fishers' organization to national states and EU will allow emerging such local practices in a structured condition in the Mediterranean Sea, is still to be demonstrated. This would imply an effective bridge between top-down and bottom-up approaches, and the necessity to develop the capability to co-construct proposals from the bottom and implement them. 
As already stated, co-management schemes would be instrumental, since by definition they need collaboration among different administrative scales and stakeholders to be bridged. The latter key factor could be achieved only if fishers will change their vision and institutions will complete the process of power derogation that is linked to co-management. For instance, pertaining fishers, they would need to shift from short-term to long-term strategies, and from single fisher to communitywide perspectives, as well as to acknowledge the environmental effects of fishing facing the challenges (and opportunities) that sustainability entails, including the need to engage in the management discourse and relate to the policy environment. In the institutional context, administrations should not only accept the challenge of sharing power, but also promote effective actions to support such process. Examples include rearticulating roles and functions, to support bottom-up community based experiences and skills, to adopt evidence-based management, to promote participatory science and the development of new skills by fishers to enter into the adaptive management discourse.

All this would also entail establishing a process that reconciles the needs of different métiers (e.g. SSF vs. large vessels), and bridge knowledge systems and administrative/spatial scales (Reid et al., 2006). The examples given above of the enforcement of LMPs for red shrimp, sand eels and small transparent goby, as well as those related to LMP in Sicily and the fishing reserve in France, show us that this goal has been already achieved, although in a small number of cases as compared to the whole Mediterranean fisheries.

\section{Conclusions}

Historical features of local fishing communities and management practices in the Mediterranean Sea can teach us several elements to be considered to improve current management. The recent shift of CFP towards a more decentralized management increased the role of national fishers' organization to define management rules and their implementation approach at regional/sub-regional level. However, 
this role must be counterbalanced with a strong capability to dialogue with local fishing communities and include them in the management discourse, as in the past. Co-management could represent a valuable approach to engage local fishers and their communities, allowing them to play a role in defining rules and in monitoring, control, and surveillance. Basing such approach on the heirs of historical local management systems, with necessary changes where needed, would ease this process and prevent past experiences, social structures and knowledge, to be lost.

\section{Acknowledgments}

This article is based upon work from COST Action IS1403, Oceans Past Platform (OPP), supported by COST (European Cooperation in Science and Technology). This study was benefited from discussions with colleagues of the ICES Working Group on the History of Fish and Fisheries.

\section{References}

Alegret, J.L., 1996. Ancient Institutions Confronting Change: the Catalan Fishermen's Cofradias, in: Crean, K., Symes, D. (Eds.), Fisheries Management in Crisis. Fishing New Books, Oxford, pp. 9298.

Alegret, J.L., 1999a. Space, Resources and History: The Social Dimension of Fisheries in the Northwest Mediterranean, in: Symes, D. (Ed.), Europe's Southern Waters: Management Issues and Practise. Fishing New Books, Oxford, pp. 55-65.

Alegret, J.L., 1999b. Anthropology of fisheries governance: the incipient failure of collective action in Catalan Cofradías. Europaea II:45-64.

Alegret, J.L., 2016. Les Confraries de Pescadors a Espanya, in: Sànchez Lizaso L. (Ed.), La Pesca a la Mediterrània, Publicacions de la Universitat d'Alacant, pp. 47-54. 
ArtFISHMed, 2017. Report of ArtFISHMed project - questionnaires in Chioggia and Caorle.

548

549

550

http://www.artfishmed.eu/wp-content/uploads/2017/02/ArtFishMed_Presentazione-Chioggia.ppsx;

http://www.artfishmed.eu/wp-content/uploads/2017/02/ArtFishMed_Presentazione-Caorle.ppsx

(accessed 01.04.2017).

Bavinck, M., Jentoft, S., Pascual-Fernández, J.J., Marciniak, B., 2015. Interactive coastal governance:

The role of pre-modern fisher organizations in improving governability.Ocean Coast Manage, 117, 52-60.

Buonfiglio, G., Coccia, M., Ianì, E., 2011. L'associazionismo cooperativo nella pesca, in: Cataudella, S., Spagnolo, M. (Eds.), Lo stato della pesca e dell'acquacoltura nei mari italiani, Ministero Politiche Alimentari Agricole e Forestali, Rome, pp. 237-242.

Cardinale, M., Scarcella, G., 2017.Mediterranean Sea: a failure of the European fisheries management system. Front. Mar. Sci.4:72. doi: 10.3389/fmars.2017.00072

Cazalet, B., Chaboud Chr., Féral, F., Reyes, N., Rubin, A., 2013. La Pêche au Petit Métier en Languedoc-Roussillon : définition d'une échelle de gestion pertinente, présentation à l'Association Française d'Halieutique, 17 au 21 juin Montpellier 2013. Available at: http://halieutique.agrocampusouest.fr/afh/forum11/Presentation/Cazalet.pdf

Chaboud, C., Cazalet, B., Reyes, N., Rubin, A., 2015. Enquête sur la petite pêche en LanguedocRoussillon. Rapport du programme Polypêche, IRD, Fondation France, Marbec.

Churchill, R., 1977. The EEC fisheries policy: Towards a revision. Mar. Policy, 1(1), 26-36.

Coll, M., Piroddi, C., Steenbeek, J , Kaschner, K., Ben Rais Lasram, F., Aguzzi, J., Ballesteros, E., Nike Bianchi, C., Corbera, J., Dailianis, T., Danovaro, R., Estrada, M., Froglia, F., Galil, B., Gasol, J.M., Gertwagen, R., Gil, J., Guilhaumon, F., Kesner-Reyes, F., Miltiadis-Spyridon, K., Koukouras, A., Lampadariou, N., Laxamana, E., López-Fé de la Cuadra, C.M., Lotze, H.K., Martin, D., Mouillot, D., Oro, D., Raicevich, S., Rius-Barile, J., Saiz-Salinas, J.I., San Vicente, C., Somot, S., José 
571 Templado, J., Turon, X., Dimitris, V., Villanueva, R., Voultsiadou E., 2010. The biodiversity of the

572 Mediterranean Sea: estimates, patterns and threats. PLoS One, 5(8). e11842. doi/10.1371/

573 issue.pcol.v02.i09

Decugis, C., 2009. The prud'homies, collective fisheries management in the Mediterranean. Proceedings of the International Meeting of Small Scale Professional Sea and Inshore Fisheries, 2527 of November 2009, Biarritz.

EC, 2002. Council Regulation (EC) No 2371/2002 of 20 December 2002 on the conservation and sustainable exploitation of fisheries resources under the Common Fisheries Policy

EC, 2006. Council Regulation (EC) No 1967/2006 of 21 December 2006 concerning management measures for the sustainable exploitation of fishery resources in the Mediterranean Sea, amending Regulation (EEC) No 2847/93 and repealing Regulation (EC) No 1626/94

EEC, 1957. Treaty establishing the European Economic Community (EEC Treaty).

EEC, 1970a. Regulation (EEC) No 2141/70 of the Council of 20 October 1970 laying down a common structural policy for the fishing industry.

EEC, 1970b. Regulation (EEC) No 2142/70 of the Council of 20 October 1970 on the common organisation of the market in fishery products.

EEC, 1983. Council Regulation (EEC) No 170/83 of 25 January 1983 establishing a Community system for the conservation and management of fishery resources.

EEC, 1992. Council Regulation (EEC) No 3760/92 of 20 December 1992 establishing a Community system for fisheries and aquaculture.

EU, 2013. Regulation (EU) No 1380/2013 of the European Parliament and of the Council of 11 December 2013 on the Common Fisheries Policy, Amending Council Regulations (EC) No 1954/2003 and (EC) No 1224/2009 and Repealing Council Regulations (EC) No 2371/2002 and (EC) No 639/2004 and Council Decision 2004/585/EC Official Journal of the European Union, Brussels. EU, 2014. Regulation (EU) No 508/2014 of the European Parliament and of the Council of 15 May 2014 on the European Maritime and Fisheries Fund and repealing Council Regulations (EC) No 
2328/2003, (EC) No 861/2006, (EC) No 1198/2006 and (EC) No 791/2007 and Regulation (EU) No 1255/2011 of the European Parliament and of the Council.

Faget, D., 2011. Marseille et la Mer, Hommes et Environnement marin (XVIII-XX siècle). Presses Universitaires de Provences-Presses Universitaires de Rennes.

FAO, 2016. The State of Mediterranean and Black Sea Fisheries. General Fisheries Commission for the Mediterranean. Rome, Italy.

Féral, F., 1990. La prud'homie des pêcheurs de Palavas, doit et économie de l'environnement. Lyon: Publication Périodiques Spécialisées.

Fortibuoni, T., Gertwagen, R., Giovanardi, O., Raicevich, S., 2014. The Progressive Deregulation of Fishery Management in the Venetian Lagoon After the Fall of the Repubblica Serenissima: Food for Thought on Sustainability. Global Bioethics. 25(1), $42-55$ (DOI 10.1080/11287462.2014.894707).

Frangoudes, K., 1997. Marine Resources Management in the French and Greek Mediterranean. Final report. MARE/EU Contract EV5V_CT94-0386. Brest: OIKOS.

Frangoudes, K., 2001. France, in: Symes, D., Phillipson, J. (Eds), Inshore Fisheries Management. Kluwer Academic Publishers, pp. 318.

Frangoudes, K., Garineaud, C., 2015. Governability of Kelp Forest Small Scale Harvesting in Iroise Sea, in: Chuenpagdee, R., Jentoft, S. (Eds.), Interactive Governance for Small Scale Fisheries. Mare Publications Series 13, Springer.

Gray, T., Hatchard, J., 2003. The 2002 reform of the Common Fisheries Policy's system of governance—rhetoric or reality? Marine Policy.27(6), 545-554.

Gutierrez, N.L., 2013. Management and co-management options for small-scale fisheries in the Mediterranean and Black Sea. Background paper - Thematic session II. First Regional Symposium on Sustainable Small-Scale Fisheries in the Mediterranean and Black Sea. Pp. 42. 
620 Gutiérrez, N.L., Hilborn, R., Defeo, O. 2011. Leadership, social capital and incentives promote 621 successful fisheries. Nature. 470, 386-389.

622 Hardin, G., 1968. The tragedy of the commons. Science. 162, 1243-1248.

623 Jentoft, S., 2003. Co-management - the way forward, in: Wilson, D.C., Nielsen, J.R., Degnbol, P. 624 (Eds.), The fisheries co-management experience: accomplishments, challenges and prospects. 625 Kluwer Academic Publishers, 1-13.

626 Levi-Morenos, D., 1919. L’Utilizzazione razionale e intensiva della Laguna di Venezia per 627 l'approvvigionamento dei nostri mercati. Memorie del Regio Comitato Talassografico Italiano, 72 , $628 \quad 1-98$.

629 Lleonart, J., Demestre, M., Martín, P., Rodón, J., Sainz-Trápaga, S., Sánchez, P., Segarra, I., Tudela, 630 S., 2014. The co-management of the sand eel fishery of Catalonia (NW Mediterranean): the story of 631 a process. Scientia Marina. 78S1, 87-93.

632

633

634

635

Mackinson, S., Wilson, D.C.K., 2014. Building bridges among scientists and fishers with participatory action research. In: Urquhart, J., Acott, T., Symes, D.,Zhao, M. (Eds.),Social Issues in Sustainable Fisheries Management. Springer Netherlands, pp. 121-139.

MAPAMA, 2013. Ministerio de Agricultura y Pesca, Alimentación y Medio Ambiente. Orden AAA/923/2013, de 16 de mayo, por la que se regula la pesca de gamba rosada (Aristeus antennatus) con arte de arrastre de fondo en determinadas zonas marítimas próximas a Palamós.

Neil, D.T., 2002. A thousand years of human-coastal interactions in Venice: Lessons from the serene republic. Coast to Coast. $318-321$.

Ostrom, E., 2009. A general framework for analyzing sustainability of social-ecological systems. Science. 325(24), 419-422. 
642

643

644

645

646

647

648

649

650

651

652

653

654

655

656

657

658

659

660

Pascual-Fernadez, J., Frangoudes, K., Williams, S., 2005. Local Institutions. In: Kooiman, J., Bavinck M., Jentoft, S., Pullin, R., (Eds.), Fish for Life: Interactive governance for Fisheries, Amsterdam University Press, pp. 153-172.

Raicevich, S., Giovanardi, O., 2013. I pescatori, protagonisti mancati della gestione della pesca. In: Bulian, G., Raicevich, S., (Eds.). In mare altrui - Pesca e territorialità in ambito interdisciplinare, Aracne Editrice, Rome, pp. 283-318.

Raicevich, S., Fortibuoni, T., Franceschini, G., Celić, I., Giovanardi, O., 2011. The use of Local Ecological Knowledge to reconstruct the history of marine animal populations. Potential and limitations, in: Gertwagen, R., Fortibuoni, T., Giovanardi, O., Libralato, S., Solidoro, C., Raicevich, S. (Eds.). When humanities meet ecology. Historic changes in Mediterranean and Black Sea marine biodiversity and ecosystems since the Roman period until nowadays. Languages, methodologies and perspectives. Proceedings of the $1^{\text {st }}$ international HMAP Mediterranean and Black Sea project Summer School. Trieste (Italy, $31^{\text {st }}$ August $-4^{\text {th }}$ September 2009), pp. 81-94. Available at: http://www.isprambiente.gov.it/en/publications/proceedings/hmap-international-summer-school-

when-humanities

Raicevich, S., Grati, F., Giovanardi, O., Sartor, P., Sbrana, M., Silvestri, R., Baino, R., Andaloro, F, Battaglia, P., Romeo, T., Spagnolo, M., Dubois, M., in press, a. The unexploited potential of smallscale fisheries in Italy: analysis and perspectives on the status and resilience of a neglected fishery sector, in: Pascual-Fernandez, J., Pita, C., Bavinck, M. (Eds.). Small-Scale Fisheries in Europe: Status, resilience and governance. MARE Publication Series, Springer, in press.

Raicevich, S., Dubois, M., Bullo, M., Franceschini, G., Mion, M., Nalon, M., Piras, C., Sabatini, L., Fortibuoni, T., Celić, I., Mariani, A., Serra, S., Fusari, A., Bulian, G., Giovanardi, O., in press, b.

The Italian job: Navigating the (im)perfect storm of participatory fisheries research in the Northern Adriatic Sea, in: Holm. P., Hadjimichael. M., Mackinson. S. (Eds.). Bridging the gap: Collaborative research practices in the fisheries. MARE Publication Series, Springer. 
667

668

669

670

671

672

673

674

675

676

677

678

679

680

681

682

683

684

685

686

687

688

689

Reid, W.V., Berkes, F., Wilbanks, T., Capistrano, D. (2006). Bridging Scales and Knowledge Systems. Concepts and Applications in Ecosystem Assessment. Island Press, 368 pp.

Reyes, N., Bahuchet, Wahiche, J.D., 2015. Quelle définition des "petits métiers" de la pêche? de l'analyse juridique à l'ethnologie des pêcheurs lagunaires languedociens in Revue d'ethnologie [en ligne], 7/ 2015, consulté le 30 septembre 2015, DOI: 10.4000/ethnoecologie.2221

Salomon, M., Markus, T., Dross, M., 2014. Masterstroke or paper tiger - The reform of the EU' s Common Fisheries Policy. Marine Policy. 47, 76-84.

Scarpa, G., 1996. Mariegola della Scuola di Sant'Andrea de’ Pescatori. Venice: Il Leggio.

Seytre, C., Francour, P., 2008. Is the Cap Roux marine protected area (Saint-Raphaël, Mediterranean Sea) an efficient tool to sustain artisanal Fisheries? First indications from visual censuses and trammel net sampling. Aquatic Living Resources, 21, 297-305.

Song, Y.H., 1995. The EC's common fisheries policy in the 1990s. Ocean Development \& International Law. 26(1), 31-55.

Stephenson, R. L., Paul, S., Pastoors, M. A., Kraan, M., Holm, P., Wiber, M., Mackinson, S., Dankel, D.J., Brooks, K., Benson, A., 2016. Integrating fishers' knowledge research in science and management. ICES Journal of Marine Science. 73(6), 1459-1465.

Symes, D., Steins, N., Alegret, J., 2003. Experiences with fisheries co-management in Europe, Fish and fisheries series 26. Dordrecht: Kluwer Academic Publishers.

Tempier, E., 1986. Prud'homie et régulation de l'effort de pêche. Economie Méridionale. 34 (133-4), 41-50.

Wilson, D.C., del Valle, I., Jessen, R., Motos, L., 2006. The knowledge base as a process. In: Motos, L., Wilson, D.C. (Eds.), The Knowledge Base for Fisheries Management. Pergamon Press (Developments in Aquaculture and Fisheries Science). 36, 1-26. 
Wilson, D.C., 2010. The paradoxes of transparency: science and the ecosystem approach to fisheries

691

692

693

694

695

696

697

698

699

700

701

\begin{tabular}{|l|c|c|c|}
\hline $\begin{array}{l}\text { Co-management } \\
\text { features }\end{array}$ & Cofradias & Prud'homies & Yraglie \\
\hline $\begin{array}{l}\text { Restricted access to } \\
\text { fishing }\end{array}$ & Yes & Yes & Yes \\
\hline $\begin{array}{l}\text { Territorial use rights for } \\
\text { fishing (TURFs) }\end{array}$ & Yes & Yes & No \\
\hline Self-enforcement & Yes & Yes & No \\
\hline Self-management & Yes & Yes & Yes \\
\hline Welfare & Yes & Yes & No \\
\hline $\begin{array}{l}\text { Election } \\
\text { representatives }\end{array}$ & Yes & No & Yes \\
\hline $\begin{array}{l}\text { Judging of infringements } \\
\text { by the corporation }\end{array}$ & Yes & Yes & \\
\hline $\begin{array}{l}\text { Strong leadership of } \\
\text { representatives }\end{array}$ & Yes & & Yes \\
\hline
\end{tabular}

management in Europe. Amsterdam University Press.

WWF, 2009. Gestion régionale: La pêche et l'écologie main dans la main, Base de Réflexion,

Conférence sur la gestion régionale des pêches. Bruxelles 29 septembre 2009.

Tsikliras, A.C., Dinouli, A., Tsikliras, V.Z., Tsalkou, E., 2015. The Mediterranean and Black Sea

Fisheries at Risk from Overexploitation. PloS ONE, 10: e0121188. DOI 10.1371/journal.pone.

0121188.

\section{Tables}

Table 1. Co-management attributes that characterized historical fish corporations in the Mediterranean Sea. Attributes were defined according to Gutierrez et al. (2011) framework. 
705

706

707

708

709

710

711

\section{Legend to figure}

Figure 1. Locations where Cofradias (Spain; red rectangle), Prud'homies (France; green rectangle) and Fraglie (Italy-Venice Lagoon; blue rectangle) corporations were historically present in the continental Mediterranean Sea. 
